\title{
Recomposing the Critical/Liberal/ Arts
}

\author{
J. Allan Mitchell ${ }^{a}$, Julie Orlemanski and Myra Seaman ${ }^{c}$ \\ ${ }^{a}$ Department of English, University of Victoria, Victoria, British Columbia, Canada. \\ ${ }^{\mathrm{b}}$ Department of English, University of Chicago, Chicago, IL. \\ 'Department of English, College of Charleston, Charleston, SC.
}

postmedieval: a journal of medieval cultural studies (2015) 6, 361-374.

doi:10.1057/pmed.2015.33

Experiments in thinking, the artful transmission of knowledge and scholarly play have a critical dimension that often goes unrecognized. Alternative modes of understanding render norms visible and make conventions sidesteppable. Inventive practices show the contingency of what has been established and adumbrate how it might be different. These were some of the convictions behind Critical/ Liberal/Arts, a pair of symposia sponsored and organized by the BABEL Working Group in 2013 and held, respectively, at the University of California, Irvine and at The Graduate Center, City University of New York. ${ }^{1}$ The two day-long events included scholars, artists and activists and sought to foment scenes of thinking and being together not centered on a single milieu, one form of apprenticeship, or exclusive criteria of validity. The wager of the symposia was this: even as the 'hermeneutics of suspicion' has fallen under suspicion and many react against 'symptomatic criticism' and 'paranoid reading,' critique has not outlived its usefulness. Indeed, alternatives to entrenched critical habits might extend and intensify the power of critical inquiry. We invited presentations that brought together practices divided by recent polemics: the critical arts of resistance, protest, questioning and self-reflexivity, and the ludic disciplines of creation,

1 A full list of participants and the titles of their presentations appears as an appendix to this introduction, and the website archiving the symposia can be found at babelsymposia 2013.org/. 
collaboration, celebration and play. Presenters were encouraged to see criticism in terms of making, doing and imagining - perhaps to discover creation and critique inhering in one another, or wending apart, or crossing one another again and again like a pair of knives being whetted or like the faces of a Mobius strip. This volume gathers many of the ideas and objects shared in the course of Critical/ Liberal/Arts and pursues further inquiries sparked by those conversations. Eleven of the twenty-one original presentations have been reimagined for publication.

The conversation began when the three of us who organized the symposia (and who serve as editors for the present volume) expressed both excitement about and unease with the state of literary studies. There were wars and rumors of war against adversarial 'critique,' a general turning away from the 'negative' stance of the critic whose 'persona' was accused of defensiveness, displeasure, mistrust and desire for mastery. In accounts of the alleged 'post-critical' state of the field, description claimed ascendance over interpretation and intervention; 'making' surged ahead of explanation and explication; surfaces, rather than symptoms, seemed to answer the needs of the day. Meanwhile new critical methods, collaborations and forms of public engagement were appearing, despite the so-called crisis in the humanities. Even a passing glance at higher education turned up projects that transcended traditional rubrics and refused to remain in their respective scholarly domains, but rather crossed out of academia and continued on to other planes of social practice. These projects represented serious commitments to tinkering, mapping, constructing, organizing, blogging, protesting, ornamenting, fantasizing, healing, documenting, inventing, occupying, wandering and more. They also embodied reflexive tactics for surviving, and flourishing, in the conditions of marketization and precarity that characterize twenty-first-century universities and life more generally. From the perspective of both theory and practice, then, it seemed to us that the moment was at hand to reflect anew on what we do when we study literary and cultural phenomena, when we engage the past, and when we teach, read, write and think. Now was our chance to redefine those relationships, to experiment with various ways forward and test the stakes.

But the frameworks available for the conversation felt limiting. The prevailing polemics tended to reinforce and naturalize divisions that were neither necessary nor salutary, and sometimes reproduced the antagonisms they were criticizing. They failed to describe many of the critical legacies and companionable acts that made us want to be literary scholars in the first place, and they disregarded the extraordinary projects currently underway inside and outside academia, projects that cut across the conventional distinctions within knowledge production: distance and involvement, criticism and aestheticism, sensation and reflection, detachment and attachment, interrogation and incorporation, control and loss of control before the objects of our study. We thought: we need critique not in opposition to creation, immersion and affirmation, but in concert with them. So Critical/Liberal/Arts took a different tack. Over two days, and in the 
conversations preceding and following those two days, we sought to stage unconventional encounters and to generate local states of disequilibrium in the circulation of laboring, thinking bodies, and in the flows of information, resources, chit-chat and debate. Delivered by speakers from various positions in academia's hierarchy and from outside the university, the presentations would include exhibition, performance, demonstration, institution-founding, film screening and guided meditation. They would involve expressive modes quite different from the usual sort of analytic thinking we associate with critique, but would be critical interventions even so - indeed, they would be radical rethinkings.

So we asked: What different faces might critique have today? What does it feel like? What does it do? What does it mean to be 'uncritical' or 'anti-critical'? How do we engage in criticism and invention against the actuarial interests of the corporate university? Can we 'afford' to nurture speculative creation, or pure science, in the so-called age of austerity? Do delight, rapture or the drift of daydreams have a role in criticism? Is there value in maintaining what separates the injunctions to critique and to create? How and to what ends might our practices cross-pollinate the sciences and the fine arts? Or politics and aesthetics? Or the future and the past? The symposia's participants both enacted and reflected on such entanglements, offering new models of critical invention under the rubric Critical/Liberal/Arts.

\section{Art and the Liberal Arts}

The title shared by this special issue and the two symposia seeks to constitute a field of play, a framework in which definitions might be ventured, tactics tried out against others and new games invented. Critical/Liberal/Arts sets three terms in dynamic and recombinatory relation; it wonders how art, the liberal arts, and the arts of criticism and critique might sit together. The slashes separating the terms may seem to cast 'critical' and 'liberal' as alternatives, but our hope is rather that the oblique strokes conjure a different set of relations - as if to mark ratios or fluctuations rather than stable divisions, on the assumption that nothing about the words should be taken for granted. The ambiguity of our defining terms is one reason to continue to subject them to continual debate and play and, yes, critique.

During the Middle Ages, the epistemological category of ars could refer to knowledge of a practical kind, as opposed to scientia, or more theoretical knowledge. Perfect Aristotelian scientia was to be based on first principles and advanced by logical deduction; it was 'speculative' in its concern with establishing truths, rather than achieving a certain outcome. Ars, by contrast, was knowledge oriented toward worldly ends, not quite systematic, inductive rather than deductive. This is one sense of the 'arts' in the title: the plural, unpurified arts of knowledge, fueled by desires in and for the world. Yet, to take another 
lesson from medieval epistemology: in medieval Latin usage, ars and scientia (or disciplina) were often deployed interchangeably, just as the boundaries between what we consider secure knowledge and contingent apprehension are shifting and unstable. As ever, what is distinguished theoretically often falls back into indistinction, again enmeshed.

In Critical/Liberal/Arts, one might also see an apparition of the seemingly ineluctable 'conflict of the faculties' that stretches from the ancients to the moderns. The liberal arts, after all, were partly a creation of medieval universities whose early purpose was to organize diverse faculties and professional pursuits within new institutional structures. The trivium of grammar, rhetoric, and logic and the quadrivium of arithmetic, geometry, music, and astronomy systematized academic knowledge and provided battle lines for a significant number of intellectual and institutional skirmishes. It was also a synthetic framework, combining what look to us like quite different 'verbal' and 'quantitative' disciplines. Yet these artes liberales stood together to the exclusion of the artes mechanicae, like architecture, warfare, tailoring and metallurgy, held by medieval thinkers to be more 'servile' or 'vulgar' branches of practical learning. Alternative forms of knowledge transmission such as apprenticeships and guilds were consequently left out of universities. These and other conflicts of the faculties are easy enough to generalize, extending to the agonistic relationship of poetry and philosophy (Plato), secular literature and sacred doctrine (from the Patristics down to medieval Papal policy), onward to Immanuel Kant's rival 'faculties,' C.P. Snow's 'two cultures' and the contemporary management structures of universities and the 'information economy' more broadly. We might note that, in each case, the divisions between kinds of knowledge tend to be normative, not simply descriptive, and to set off some branch of learning as higher, more autonomous, more rational or closer to the truth than others. The medieval artes liberales are instructive for seeming so capacious and crossdisciplinary, but they were also defensive and territorial in their self-separation from commercial and manual pursuits. The 'liberal/arts' of our title points to these histories of learning's division and institutionalization and to the ongoing negotiation of those conflicts. Critical/Liberal/Arts recognizes the palpable realities of learning's taxonomies - of differential funding structures, varying levels of status and opportunity and access, and the relative ease or difficulty of working across boundaries. In light of these conditions, the symposia and this volume have sought, at least locally and provisionally, to give occasion for works that realize alternative architectures of learning and living together.

In the United States today, a 'liberal arts degree' connotes an attainment at some remove from pre-professional or vocational training, one originally justified as the background proper for citizens of a democratic society. The defense of learning for its own sake, at a distance from its instrumentalization, is an old one. To medievalists, it calls to mind, say, John of Salisbury (d.1180) claiming that the arts need to be defended against entrepreneurial types who reject the trivium in 
favor of professional training in the pursuit of personal wealth. Controversies over the value of otium and negotium are perennial and suggest that 'crisis' over the place of the humanities in relation to daily business may be inevitable. Intellectual autonomy will always be hard-won because scholarship (from Latin schola, deriving from the Greek for leisure as well as learning) can exist only within networks of material and social co-dependency. Speculative freedom, or the project of learning for the sake of learning, is a collective achievement (even if not equally accessible to all). The ambient imperative to justify what we do was in evidence throughout Critical/Liberal/Arts. This need seemed to derive, at least in part, from the managerial push for assessment and outcomes - and the fact that value in contemporary higher education is most frequently identified with economic value, monetization. Our title gestures toward this problematic as well: unmoored from 'arts,' 'liberal' slides toward the neoliberalism of laissez-faire capitalism and market-driven choice. The 'neoliberal university' is one that feels saturated by the structures of for-profit corporations. The imperative that we justify ourselves also drifts like a miasma from the recent pejoration of the term 'liberal' by conservative ideologues, who seek to curtail academics' freedoms of expression when those views differ sharply from their own. Yet the task of explaining anew the value of the humanities and the criteria of their excellence is not merely defensive or reactive. Fundamental openness to different formulations of knowledge sustains the liberal arts: as Stefan Collini writes, 'no starting-point is beyond re-consideration, because no assumptions (about how societies change or people act or how meanings mean) are beyond challenge, because no vocabulary has an exclusive monopoly' (Collini, 2012, 66).

Most participants and audience members at the symposia have been deeply involved in the humanities and fine arts, whether inside or outside of universities. We have every reason to want to preserve the liberal arts in their non-instrumentalized, speculative, experimental and playful modes, as an infrastructure of initiation into learning's rigors and joys. Yet, following Jeffrey J. Williams in his important essay 'History as a Challenge to the Idea of the University,' we believe we need more than an academic 'politics of nostalgia,' idealizing the university of the past as a 'refugium or humanistic enclave.' Williams calls for us to 'imagine new possibilities,' rather than resort to a false sentimentality - and it is just this forward-looking imagination that Critical/Liberal/Arts has sought to be a part of (Williams, 2005, 69). Indeed, several of the contributors tracked new paths through or beyond the bureaucracy of the contemporary university - as in Gaelan Gilbert's discussion of alternative 'outstitutions' and forms of 'mendicancy,' in Henry Turner's 'Society for the Arts of Corporation' with its cultivation of membership, legal documentation and institutional governance free from any interest but incorporation itself, and in Ammiel Alcalay's role in founding the deeply collaborative book series Lost \& Found: The CUNY Poetics Document Initiative.

The final word of the title also stands alone: arts in the sense of fine arts, objects of beauty, what we gaze at in museums and galleries and watch in theaters, what 
works on us through sensory means and affects us as sensuous creatures. Critical/ Liberal/Arts sought to showcase the mutuality of making and understanding, creating and criticizing. The program of the two symposia included a screening of Thom Andersen's $16 \mathrm{~mm}$ short film 'Get Out of the Car,' in which the filmmaker challenges some of the assumptions of his own earlier film about Los Angeles; a poem by Eleanor Johnson generated from a chance encounter with a book by the French naturalist Jean Rostand; a reading by medievalist/novelist Bruce Holsinger of his historical fiction, which vibrated with the rhythms of both Middle English and hardboiled noir and was the product as much of his scholarly expertise as his creative imagination; a comic slideshow extravaganza by the Hollow Earth Society (Ethan Gould and Wythe Marschall), or what they called a 'pedagogical management strategy bootcamp'; and the presentation of a collaborative art project by Marina Zurkow and Una Chaudhuri that used aesthetic provocations to reorient us affectively toward climate change. One preoccupation was in discovering in things the potential to jog the mind, as in the flotsam and jetsam Jamie Skye Bianco found awash on Dead Horse Bay and the Rockaway Peninsula. Throughout these events we were presented with inventive means of training attention on matters (a toad, garbage, Swiss cheese, geometrical figures, the typo) that too easily slide into the background. There was a welcoming of the aleatory, abjected and wasted into our field of concern, something theorized in Eirik Steinhoff's account of poetry as 'a means for cultivating and activating the presence of chance, on behalf ... of our ongoing improbable happinesses.' Even inadvertency and ruination, as dramatized in Dadaism and the film The Five Obstructions (discussed by Aaron Kunin), could be constructive and impose creative obligations. Vectors of lyrical, emotional, and aesthetic force also moved through seemingly more conventional modes of presentation, as in Colby Gordon's gorgeous evocations of fecund decay in Antony and Cleopatra and Bianco's coordination of densely citational prose with images and video. These many manifestations of art and artfulness raised a second-order series of reflections, about how aesthetic and affective elements, fiction and sentiment, beauty and audiovisual mediation fit within knowledge. This is part of the unsettledness of Critical/Liberal/Arts: Does yoking together art and critical inquiry undo what is distinctive to each? Our wager is that no, it does not - but the combination of what is aesthetic, emotional and ideational does create the need to renegotiate the forms of our understanding.

Many moments in the flow of the symposia realized the alchemical mixture of method-seeking, provocation, conjecture and yielding that the previous paragraphs seek to describe. One of the most vivid took place near the end of the day's events at the Graduate Center, CUNY. Marina Zurkow and Una Chaudhuri were presenting aspects of their collaborative art project Dear Climate, and they asked the assembled audience to close our eyes and join them in a 'guided meditation.' A bell rang, and two voices began to resonate on the sound-system, along with a background of ambient sound, drawing us through the entire ecosystem of 
LaGuardia airport: 'May all feral cats be happy and free. May all squirrels be happy and free. May all coffee, bagel, magazine, and gadget concession workers be happy and free ...' At the end of a long day of following claims and assimilating ideas, the simplicity of these blessings was a cognitive relief, but also an unsettling one. Was this a parody of New Age mysticism? A satire of the ecological and materialist perspectives shared by some in the room? Or was it earnest, piously calling for the happiness and freedom of (among others) bacteria, particulate matter, Department of Homeland Security officers and jet fuselage? The room filled with a weird, uncertain calm as the roughly seven-minute recording played out. The experience was nearly exactly the opposite of what we associate with critical knowledge in its narrow definition, as something that is secular, argumentative, something that tests propositions and reframes phenomena and incites questioning alertness in those who follow its claims. By contrast, the peculiar meditation asked for acquiescence and release. It seemed religious, at least vaguely so. Its mode was not indicative or declarative, but jussive: may it be that all these entities are happy and free. The meditation acted upon us through sound and mood. It was in the aftermath of thinking about it, in comparing it to other presentations and our assumptions of what knowledge should be, of how we should talk about something as serious as climate change - it was in these subsequent discussions that the critical aspects of the meditation stood out in high relief, as did the alternative possibilities it opened onto. ${ }^{2}$

\section{Critique and the Critical Arts}

As some of the examples already suggest, we are taking 'critique' to refer to heterogeneous practices of explanation, of analysis and of better accounting of this world in order to pursue alternative versions of it. This is to think of criticism as the creative practice of futurition. 'Critique is not satisfied with what is given, and wants to try something else. To make something else,' remarks Critical/ Liberal/Arts participant Aaron Kunin. 'Critique is generative.' Ours may sound like an overly ecumenical account of critique that sacrifices in conceptual clarity what it gains in inclusiveness. But in fact 'critical' is an enormously slippery and capacious term even within present-day debates. 'Critical' is the adjectival form of both 'criticism' and 'critique,' and both of these nouns have complex histories of usage. When 'critique' entered the English language in the first half of the eighteenth century, the two nouns were largely interchangeable: a critique was a review, an essay in criticism, on a literary or artistic work (OED). 'Criticism,' from the time of its English origins in the early seventeenth century, has referred to acts of evaluation, 'especially,' as the Oxford English Dictionary notes, 'the passing of unfavourable judgement; fault-finding, censure.' A negative inflection continues into the present, in the everyday, colloquial meanings of 'criticize' or
2 The guided meditation can be listened to online; see 'Laguardia' at www.dearclimate. net/\#/podcast. 
'critical' as a form of carping: Don't be so critical. Yet together with some kind of modifier, 'criticism' and 'critic' - as in 'art criticism,' 'New Criticism,' 'film critic,' 'food critic' - denote the coordinate exercise of taste, expertise, and discernment in a more neutral register, keyed to both appreciation and discrimination. The academy has not historically had a monopoly on such critical arts: journalists, amateurs, connoisseurs, intellectuals of all stripes, men (and women) about town, all might cast a critical eye on aesthetic and commodity productions.

'Critique' also has specialized and contested philosophical senses deriving from the three critiques of Immanuel Kant (d.1804) devoted to the human capacities to experience, act and judge. The Kantian legacy has been challenged by the likes of Whitehead, Deleuze and Badiou, among others who have wished to return to what can be characterized as pre-critical metaphysics. In this tradition Quentin Meillassoux's After Finitude repudiates the Kantian 'correlate' of mind and matter (that is, 'the idea according to which we only ever have access to the correlation between thinking and being, and never to either term considered apart from the other'; Meillassoux, 2008, 5), in turn catalyzing movements such as speculative realism and object oriented ontology, which attempt to open paths to the world outside human-centered experience, action and judgment. Political ecology and so-called new materialisms have also arisen partly to occupy new spaces for speculation about things in themselves. The Marxist tradition of Kulturkritik has also been crucial to 'anti-critical' polemics; this tradition focuses attention on material conditions of labor and consumption in relation to class inequality. Broadly Marxist and leftist critique proceeds from the premise that aesthetic and cultural productions should be analyzed within economic, social and historical frameworks. The notion of ideology has been and remains motivating (as formulated by Marx and Engels, Antonio Gramsci and Louis Althusser, among others), but so is the critical agency of art itself, and that recognition has provoked various responses to material culture and materiality as such. The relative freedom of art from economic determinism was influentially elaborated by thinkers associated with the Frankfurt School, like Theodor Adorno and Walter Benjamin. The body of thinking known as political ecology maintains a similar position about critical agency and relative freedom - but about not only music and sculpture but also asbestos, dolphin pods and airport architecture. Recent rejections of Kulturkritik as a model for literary and cultural studies have tended to follow the lead of influential accounts like Paul Ricoeur's Freud and Philosophy and Foucault's 'What Is an Author?,' insofar as these could be taken to cast Marx, Freud and Nietzsche as a kind of dour triumvirate of modern critical thought (Ricoeur, [1965] 1970; Foucault, [1969] 1998). To reject ideology seems also to have entailed rejecting psychoanalysis and genealogy. Ricoeur famously calls the trio the 'masters' of the 'school of suspicion,' who have in common 'the decision to look upon the whole of consciousness primarily as "false" consciousness' (Ricoeur, [1965] 1970, 32, 33). Rejections of critique seem to have taken 
Ricoeur at his word and accepted his synthetic and provocative characterization as sufficient.

Yet importantly, Ricoeur identifies these thinkers' suspicion as a 'moment' within the foundation of something new: 'All three clear the horizon for a more authentic word, for a new reign of Truth, not only by means of a "destructive" critique, but by the invention of an art of interpreting' (Ricoeur, [1965] 1970, 33). This 'art of interpreting' is not something merely extrinsic or imposed; rather, it seeks to respond to the formative processes - of transformation and deformation and in-formation - through which the world assumes shape. In Ricoeur's words, 'all three attempted, in different ways, to make their "conscious" methods of deciphering coincide with the "unconscious" work of ciphering' (Ricoeur, [1965] 1970, 34, italics in original). The use of scare-quotes around 'conscious' and 'unconscious' suggests that these are provisional terms, indicating not the interpreter's perennial mastery, but the negotiated difference between two positions, two moments in time and two processes. Yet in some recent repudiations of critique, not only have the 'masters of suspicion' all been collapsed together, but they have also been assimilated to the quotidian usage of 'critical' as simply censorious. Rita Felski, for instance, declares that 'Critique is negative,' always marked by 'adversarial force' (Felski, 2012, italics original). She calls the attempts by some to distance critique from negative evaluation 'a tad disingenuous.' The project of, say, denaturalizing received opinions reminds us - as Felski has it - of a scene of scolding: 'The nay-saying critic all too easily calls to mind the Victorian patriarch, the thin-lipped schoolmarm, the glaring policeman' (Felski, 2012). Here there is little interest in the positive projects in which critical thought, as Ricoeur demonstrates, plays an important part. Critique is instead artificially isolated from the invention of new arts of responsiveness.

But what Felski declares disingenuous is what Critical/Liberal/Arts has set about to pursue - namely, the disaggregation of the numerous intellectual and attitudinal aspects of critique, making room for individual projects to pick their way through a variegated critical landscape. And in fact, several of the presentations at the symposia took up the task of this very decoupling, of separating critique's possibilities from attitudes of mastery or derogation. Brantley Bryant advocated an antidote at the Irvine symposium: his talk explored the critical power inhering in qualities literally pathologized by modern academia. Bryant took up the phenomenon of 'impostor syndrome' as it was established in an influential 1978 article in the journal Psychotherapy. Resisting the article's diagnostic lens, Bryant urged us instead to embrace 'that tugging, nagging feeling of being fraudulently unqualified' - of being an impostor. Working from the article's analysis of several academic women 'suffering' from impostor syndrome, he highlighted three symptoms shared by those diagnosed: ritualistic effort, a sense of inauthenticity, and misdirected charisma. In Bryant's alternative account, these qualities come instead to constitute a 'trivium of liberal impostor arts': 
3 We are intrigued by the possibilities of many of the new methods being tested in and around this debate: Moretti's 'distant reading' (Moretti, 2005, 2013), Latour's 'compositionism' (Latour, 2010), Sedgwick's 'reparative reading' (Sedgwick, 1997), Love's 'close but not deep' reading (Love, 2010) and Joy's 'weird reading' (Joy, 2013).

4 For the text of Bady's talk, see Bady (2013).
'The grammar of ritual, the logic of silence and the rhetoric of caring charm.' Such arts, in Bryant's trivium, are not obstacles to efficient learning but rather conduits to social and intellectual discovery. Impostor syndrome thus reformulated makes criticism coincide with compassion and self-doubt, and in so doing 'actively opposes the assumption of authority.' To be 'critical,' in this sense, is not necessarily to assume one particular attitude or affective comportment. Determining in advance how critique 'feels,' as many have done, delimits it too quickly. Instead, the 'critical arts' allow for various styles and strategies: furious or affirmative, certain or hesitant, cold or warm.

A diversity of postures is vital to critique, particularly to its ability to better account for this world in order to pursue alternative versions of it. Yet recent debates have gained momentum through the simplifying gesture of lumping and splitting. This maneuver first lumps together a mass of characteristics, attitudes, practices and intellectual legacies; the criteria are vague, but a smattering of examples is enough to conjure the whole lot. Then, it rejects the entirety. Such schematizing of the field can be witnessed in the debates following the special issue of Representations on 'The Way We Read Now,' edited by Stephen Best and Sharon Marcus (2009). The editors' introductory essay worked by polarizing 'surface reading' and 'symptomatic reading,' and subsequent conversations assimilated more terms to the scheme like critique, the hermeneutics of suspicion and paranoid reading (on the one hand), and reparative reading, description and reading 'with the grain' (on the other). In the end, what is lumped together and rejected doesn't sound like a critical practice that anyone actually claims as her own. In contrast, Critical/Liberal/Arts has preferred to keep the critical field open. Acts of lumping and splitting, generalization and contrast are fine creative acts in their own right, perhaps essential as a kind of motivating polemic - but we, as organizers and editors, were not going to carry out these particular acts of distinction in advance. Instead, competing accounts might play across one another in the dense thicket of the critical arts in the present, crowded with multiple traditions and practices. The upshot of Critical/Liberal/Art's many recombinations and resonances is that they mimic this thicket, where scenes of hybrid usage, contamination, cross-pollination, and redefinition abound. ${ }^{3}$

Indeed, conflict and negative affect should play important roles in the critical arts, albeit not automatic ones. Aaron Bady's presentation at the UC Irvine symposium on the 'social life of disobedience' made this point acutely. ${ }^{4}$ Bady had set out to think 'about "critique" as disobedience - or disobedience as "critique" , (Bady, 2013). Yet as he mined the Enlightenment legacies of critical thought, the historically attested separation of critique from disobedience became clear. Citing the conclusion of Kant's famous essay 'What is Enlightenment?' with its approving quotation of Frederick II's edict 'Argue all you want, but obey,' Bady continued:

argument, as mental freedom, does not imply or compel freedom to disobey. It might compel the reverse, to counsel power on how to govern better at the 
cost of acquiescing to being governed. To critique can be to obey: by applying only where obedience is not required, this kind of free speech is just the flipside of power, a kind of supplementary and enabling excess. (Bady, 2013)

We want to emphasize again with Bady that to critique is not necessarily to obey or to disobey. These are separate categories of action, with their own legacies and consequences. Bady set his analysis in dialogue with a recent event, the day in November 2011 when Occupy Cal protesters disobeyed an order to disperse and were beaten by UC Berkeley campus police. In addition to the central group of protesters, he also considered the crowds that arrived on the scene: 'Sproul Plaza just kept filling with students, many, many thousands' (Bady, 2013). Most of these thousands were not 'activists' per se; they may not have seen themselves as participating in a project of critique or protest. But they too disobeyed the order to disperse, and, as Bady remarked, 'To say that disobedience was communicative is an understatement' (Bady, 2013). Bady's talk marked both the diversity within critical practice - it may be obedient or disobedient - and the limits of 'critique' not all disobedience is critique. There are other effective tactics, other affects and behaviors and emergent social practices, with which critique might do well to seek alliance in the circumstances of the present.

Questions linger after the experiment of Critical/Liberal/Arts. When are creative acts critical enough? How might one appeal to allies who seem bound by restrictive notions of critique? When is interference more important than engagement? How can one parasitically, or symbiotically, inhabit bureaucracy and administrative demands for outcomes? And so on. But our confidence remains in the benefits of developing more rather than fewer species of Critical/ Liberal/Arts. It is in speaking in between concepts, improvising divisions of labor, scattering claims to authority, and experimenting with alternative modes of scholarship, activism and art-making that we find the enjoyment and the hope that grounds our resistance to constraint and crisis. Hospitable conditions for work inside and outside the academy depend on our holding adjacent practices together. We thank our contributors for composing these convivial interchanges that portend livable collective futures.

\section{About the Authors}

J. Allan Mitchell is Associate Professor of English at the University of Victoria in Canada. He teaches in the Medieval Studies Program and the Interdisciplinary Program in Cultural, Social and Political Thought. He is the author of Becoming Human: The Matter of the Medieval Child (University of Minnesota Press, 2014) and Ethics and Eventfulness in Middle English Literature (Palgrave Macmillan, 2009) (E-mail: amitch@uvic.ca). 
Julie Orlemanski is Assistant Professor in the Department of English at the University of Chicago. Her work has appeared in Exemplaria, postmedieval and JMEMS, and in the collections Voice and Voicelessness in Medieval Europe, Robert Thornton and His Books, A Handbook of Middle English Studies and Reading Skin in Medieval Literature and Culture. She is completing a book manuscript entitled 'Symptomatic Subjects: Bodies, Signs, and Narratives in Late Medieval England,' and her new project concerns literary and rhetorical practices of person-making in the Middle Ages (E-mail: julieorlemanski@chicago.edu).

Myra Seaman is Professor of English at the College of Charleston. She has published work in Pedagogy, JMEMS, The History of British Women's Writing, to 1500, Vol. 1 (Palgrave Macmillan, 2012) and Dark Chaucer: An Assortment (punctum books, 2012) - the last of these a collection she also co-edited, along with Burn After Reading, Vol. 1: Miniature Manifestoes for a Post/medieval Studies (punctum books, 2014), and Fragments Toward a History of a Vanishing Humanism (forthcoming from Ohio State University Press). She is a founding editor of postmedieval: a journal of medieval cultural studies and co-founder of the BABEL Working Group. Her book project 'Objects of Affection: The Book and the Household in Late Medieval England' is nearly complete (E-mail: seamanm@cofc.edu).

\section{References}

Bady, A. 2013. Bartleby in the University of California: The Social Life of Disobedience. The New Inquiry, 3 May. http://thenewinquiry.com/blogs/zunguzungu/bartleby-in-theuniversity-of-california-the-social-life-of-disobedience/.

Best, S. and S. Marcus. 2009. The Way We Read Now. Special Issue of Representations 108(1): 1-21.

Collini, S. 2012. What Are Universities For? London: Penguin.

Felski, R. 2012. Critique and the Hermeneutics of Suspicion. M/C Journal 15(1). http:// journal.media-culture.org.au/index.php/mcjournal/article/viewArticle/431.

Foucault, M. [1969] 1998. What is an Author? In Aesthetics, Mind and Epistemology, ed. J.D. Faubion, trans. R. Hurley et al., 205-222. New York: The New Press.

Joy, E. 2013. Weird Reading. Speculations 4(4): 28-34.

Latour, B. 2010. An Attempt at a 'Compositionist Manifesto'. New Literary History 41(3): 471-490.

Love, H. 2010. Close but Not Deep: Literary Ethics and the Descriptive Turn. New Literary History 41: 371-391.

Meillassoux, Q. 2008. After Finitude: An Essay on the Necessity of Contingency, trans. R. Brassier. London and New York: Continuum.

Moretti, F. 2005. Graphs, Maps, Trees: Abstract Models for Literary History. London: Verso.

Moretti, F. 2013. Distant Reading. London: Verso. 
Ricoeur, P. [1965] 1970. Freud and Philosophy: An Essay on Interpretation. New Haven, CT: Yale University Press.

Sedgwick, E.K. 1997. Paranoid Reading and Reparative Reading; or, You're So Paranoid, You Probably Think This Essay Is About You. In Touching Feeling, 123-151. Durham, NC: Duke University Press.

Williams, J.J. 2005. History as a Challenge to the Idea of the University. JAC: A Journal of Rhetoric, Theory and Politics 25(1): 55-74.

\section{Appendix}

\section{Critical/Liberal/Arts UC Irvine (19 April 2013)}

Aranye Fradenburg (University of California, Santa Barbara): "Your Brain on Liberal Arts"

Aaron Bady (University of California, Berkeley): "Representing Disobedience in the University of California"

Bruce Smith (University of Southern California): "The Politics of Sense Experience in Early Modern England"

Aaron Kunin (Pomona College): "Thinking Against"

Gaelan Gilbert (University of Victoria): "Martianus Capella and Saint Benedict: Encyclopaedic Satire and Philological Community at the Edge of Empire”

Brantley Bryant (Sonoma State University): “The Liberal Arts of Impostor Syndrome"

Thom Andersen (California Institute for the Arts): Get Out of the Car (2010)

Rebecca Davis (University of California, Irvine): “Childish Things: Charity and the Liberal Arts"

Colby Gordon (University of California, Irvine): “Shakespearean Futurism”

David Shepard (University of California, Los Angeles): "Data for New Critical Computers: The Fiction of the Digital Humanities" 


\section{Critical/Liberal/Arts the graduate center, CUNY (27 September 2013)}

Henry Turner (Rutgers University): "Universitas: On Corporate Personhood as a Critical Liberal Art, with Special Reference to Hamlet and to You"

The Hollow Earth Society [Ethan Gould and Wythe Marschall]: "Beyond U: The Organism That Therefore the Academy Is"

Eleanor Johnson (Columbia University): "Toad Poetry: A Call for a New Critical Vernacular"

Ammiel Alcalay (The Graduate Center, CUNY): "From the Cairo Genizah to Diane di Prima's Garage: Lost \& Found and the Pedagogy of Transmission"

Bruce Holsinger (University of Virginia): "Making with Gower"

Allen W. Strouse (The Graduate Center, CUNY): "Sir Orpheus as Poet, King, and Historian: Towards a Poetics of Literary History"

Jamie "Skye" Bianco (New York University): "Q3C: Queer, Creative, Critical Compositionism (or, Tooling Affection from Allure)"

Eirik Steinhoff (The Evergreen State College): "Making nothing happen, or, The figure of default: placebo, sabotage, poetry"

Michael Witmore (The Folger Library): "Fuzzy Structuralism"

Marina Zurkow (Tisch School of the Arts) and Una Chaudhuri (New York University): "Unthinking Survivalism: Inner Climate Change" 